\title{
P2X7 receptor activity landscape in rat and human glioma cell lines
}

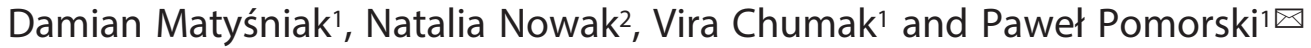 \\ 'Laboratory of Molecular Basis of Cell Motility, Nencki Institute of Experimental Biology of Polish Academy of Sciences, Warsaw, Poland; 2Labora- \\ tory of Imaging Tissue Structure and Function, Nencki Institute of Experimental Biology of Polish Academy of Sciences, Warsaw, Poland
}

$\mathrm{P} 2 \mathrm{X7}$ is a commonly expressed purinergic receptor, which functions as a cation-permeable channel in the plasma membrane. In certain circumstances, the receptor may also form a large transmembrane pore what results in cell death. $\mathrm{P} 2 \mathrm{X7}$ receptors control numerous physiological and pathological cellular processes and their overexpression is often associated with cancer progression. As nucleotides are important signaling molecules in the central nervous system, P2X7 plays also an important but ambiguous role in glioma biology with contrary observations originating from different glioma models. Therefore, the aim of our research was to investigate $\mathrm{P} 2 \mathrm{X7}$ receptor expression and functions in three human (U-87 MG, U-138 MG, U-251 MG) and one rat (C6) glioma cell lines. Although the receptor mRNA and protein were present in all the studied cells, we found profound differences in their level. We also encountered a problem with one human cell lines authenticity (U-87 MG) and excluded it from most of the experiments. Interestingly, there was no clear dependency between $\mathrm{P} 2 \mathrm{X7}$ receptor level, calcium signal and pore formation ability in the studied glioma lines. In U-138 human cell line, the receptor seemed to be inactive, while in U-251 human and $\mathrm{C} 6$ rat cell line its activation resulted in calcium influx and large pore formation. However, the viability of studied cells upon the administration of specific P2X7 agonist - BzATP - was not affected for U-138 and U-251, whereas for C6 cells a stimulatory effect was observed. Our results stress the variability of $\mathrm{P} 2 \mathrm{X7}$ signaling in glioma models and the need for future research which would take into account the complicated landscape of the receptor signaling in the brain.

Key words: nucleotide receptors, P2X7R, glioma, human brain tumors, calcium signaling

Received: 04 July, 2019; revised: 05 November, 2019; accepted: 13 March, 2020; available on-line: 18 March, 2020

『e-mail: p.pomorski@nencki.gov.pl

*Acknowledgement of Financial Support: This work has been supported by National Science Centre research grant no. 2015/17/B/ NZ3/03771

Abbreviations: ATP, adenosine triphosphate; BBG, brilliant Blue G; CNS, central nervous system; BzATP, 2'/3'-O-(4-benzoylbenzoyl) adenosine-5'-triphosphate; LDH, lactate dehydrogenase; MTS (3-(4,5-dimethylthiazol-2-yl)-5-(3-carboxymethoxyphenyl)-2-(4-sulfophenyl)-2H-tetrazolium), $\mathrm{Pl}$, propidium iodide

\section{INTRODUCTION}

Nucleotides are an important class of signaling molecules in the nervous system, what was discovered already fifty years ago (Burnstock, 1972; Burnstock, 2007). ATP and other extracellular nucleotides released by neurons
(Lopatár et al., 2015) as well as glia (Illes et al., 2019) are responsible for the communication between different CNS cells (Abbracchio et al., 2009): metabotropic, G-coupled P2Y receptors (Abbracchio et al., 2006; von Kügelgen, 2019) and P2X receptors which serve as plasma membrane ion channels (Kawate, 2017). All nucleotide receptors are characterized by different ligand affinity and downstream signaling properties. The extracellular nucleotide landscape is further complicated by the activity of ectoenzymes converting nucleotide species one to another in the extracellular space (Yegutkin, 2008). This well-established, general knowledge is however still expanding and forms a complicated network of crosstalking signaling pathways (Mutafova-Yambolieva \& Durnin, 2014; Burnstock, 2016).

In this paper, we concentrate on P2X7, formerly known also as P2Z receptor (Surprenant et al., 1996), which is one of the ionotropic nucleotide receptors, present in most of the tissues. P2X7 acts as homotrimeric ATP-gated non-selective cation channel, leading to $\mathrm{Ca}^{2+}$ and $\mathrm{Na}^{+}$influx and $\mathrm{K}^{+}$efflux. The receptor is involved in many various processes: immune response, inflammation, cell death and proliferation, cell metabolism and autophagy among others (Young \& Górecki, 2018). Interestingly, prolonged activation of this receptor in somatic cells provides to pore formation in plasma membrane permeable to large molecules (Surprenant et al., 1996). Uncontrolled and massive $\mathrm{Ca}^{2+}$ entry induces mitochondrial membrane depolarization which eventually leads to the apoptotic cell death. However, the mechanism of pore formation is not fully understood. Some reports suggest a role of another protein - pannexin-1 - in this process ( $\mathrm{Xu}$ et al., 2012), while others claim that dilation of the P2X7 channel is sufficient for the pore opening and may be an effect of cell swelling (Anastacio Alves et al., 2014). Recent work revealed also a possible role of plasma membrane lipids in the pore formation (Karasawa et al., 2017).

P2X7 is also expressed in central nervous system cells: microglia, astrocytes and oligodendrocytes, whereas its presence in neurons is still a subject of the debate (Illes et al., 2017; Miras-Portugal et al., 2017; Kaczmarek-Hajek et al., 2018). Importantly, glia and neurons use the extracellular ATP to communicate and to maintain the homeostasis in the brain; moreover, ATP may be also released from damaged CNS cells (Rivera et al., 2016). It is not surprising then, that ATP-gated P2X7 is involved in many physiological and pathological processes in CNS, such as neurotransmission (Sperlágh et al., 2002), phagocytosis during brain development (Gu \& Wiley, 2018), immunological cells infiltration (Panenka et al., 2001) as well as neurodegenerative diseases, psychiatric disorders and neuroinflammation (Sperlágh \& Illes, 2014). 
P2X7 receptor signaling is also believed to play a crucial role in gliomas which represent most of the CNS malignant tumors and are characterized with very poor prognosis (Jiang \& Uhrbom, 2012). The influence of P2X7 on glioma progression is far from unambiguous. Results obtained from mice glioma GL261showed that P2X7 expression is necessary for radiation-induced cell death (Gehring et al., 2015). Similar results on the same glioma model were obtained by (Tamajusuku et al., 2010) where the researchers observed necrotic death of the cells after P2X7 stimulation. On the other hand, studies on rat glioma model C6 mostly showed the supporting role of P2X7 in the glioma progression. (Wei et al., 2008) observed elevated P2X7 expression after the receptor stimulation, which also resulted in calcium influx and large P2X7 pore formation. However, instead of an increase in cell apoptosis, activation of P2X7 resulted in cell proliferation and migration boost. Using the same cell line in in vivo experiments, (Ryu et al., 2011) showed an increase in P2X7 expression in microglia and astrocytes associated with the tumor. The researchers also suggested a potential therapeutic profit from inhibition of P2X7 receptors by its specific antagonist BBG (Brilliant Blue $G$ ) as the tumors exposed to the inhibitor were smaller and correlated with a significantly longer lifetime of the treated rats when compared to the control. Similarly, in human glioma samples obtained from patients, (Monif et al., 2014) observed P2X7 overexpression in the tumor when compared to the normal brain, especially in the glioma cells on the tumor periphery, but also in the microglia and, to a lower extent, in the astrocytes associated with the tumor. Concordantly, it is known from long time that activated microglia show increased activation of P2X7 receptor in various pathological states (Ferrari et al., 1999; Ferrari et al., 1997; Hide et al., 2002) and it is well established that it contributes to the glioma-supporting microenvironment (Gieryng et al., 2017).

In the light of somehow contrary observations coming from different glioma models, it is undoubtedly worthy to verify and further investigate the different molecular mechanisms of P2X7 signaling in the tumor progression, especially using human tissues and cells. P2X7 role in glioma therapy may be even more important in the light of (Martins et al., 2009) observations that various chemotherapeutic agents induce ATP release from different cancer cells. Thus, the aim of the present paper was to investigate the P2X7 expression and functioning in three human glioma cell lines and compare them to rat glioma model, C6 cell line as well as to assess the influence of P2X7 receptor stimulation on the viability of the cells.

\section{MATERIALS AND METHODS}

Cell culture. Rat glioma cell line C6 and human glioma lines (U-251 MG, U-138 MG, U-87 MG) obtained from ATCC (C6), ECACC (U-251 MG and U-87 MG) and DSMZ (U-138 MG) were cultured in DMEM High Glucose medium (4.5 g/1 glucose, Thermo Fisher Scientific Inc., USA), supplemented with 10\% heat-inactivated FBS (Thermo Fisher Scientific Inc., USA). Cells were grown in standard conditions $\left(37^{\circ} \mathrm{C}, 5 \% \mathrm{CO}_{2}, 70 \%\right.$ humidity). Cell lines were routinely tested to detect mycoplasma contamination using PCR Mycoplasma Detection Kit (Applied Biological Materials Inc., Canada), according to manufacturer's instruction (see: Supplementary file 2 at https://ojs.ptbioch.edu.pl/index.php/abp/). All the experiments were performed 1-4 weeks after thawing the frozen cell lines. The cell lines used in this work have different population doubling time. C6 cell line divides fastest and before the experiments we performed 2 to 3 passages after thawing the cells. On the other hand, U251 and U138 divide slower and therefore we performed the experiments after at least 1 passage after thawing.

RNA isolation and reverse transcriptase PCR. Total RNA was extracted using GeneMATRIX Universal RNA Purification Kit (EURx, Poland). DNA removal from RNA samples was performed by treatment with DNase I (EURx, Poland). cDNA was synthesized using $1 \mu \mathrm{g}$ RNA and smART First Strand cDNA Synthesis kit (EURx, Poland) according to the manufacturer's instructions. Random hexamers were used as primers for the reverse transcription reaction. Obtained cDNA served as a template for PCR reaction using primers specific for $\mathrm{P} 2 \mathrm{X}$ receptors (Table 1). The reaction mix was as follows: 1X Buffer Gold, $2.5 \mathrm{mM} \mathrm{MgCl} 2,200 \mathrm{uM}$ dNTP Mix, $0.5 \mu \mathrm{M}$ forward and reverse primers, $1 \mathrm{U}$ Gold Taq Polymerase (Syngen Biotech, Poland), $2 \mu \mathrm{l}$ cDNA (10\% of the total post-RT mixture), in a total volume of $20 \mu \mathrm{l}$. PCR reactions were performed in MJ Mini Thermal Cycler (Bio-Rad Laboratories, Inc., USA) using the following temperature profile: initial denaturation at $95^{\circ} \mathrm{C}$ for 5

Table 1. PCR primers used for assessment of human glioma P2X receptors expression

\begin{tabular}{|c|c|c|}
\hline Receptor with Esembl genome browser ID & Sequence $5^{\prime}>3^{\prime}$ & Product length (bp) \\
\hline $\begin{array}{l}\text { P2X1 } \\
\text { ENSE00003600494 }\end{array}$ & $\begin{array}{l}\text { F: CACATCTACACCCCCAAGCACACA } \\
\text { R: TCATTCCCTITATTGTACTCCACCCGT }\end{array}$ & 256 \\
\hline $\begin{array}{l}\text { P2X2 } \\
\text { ENSE00001373821 }\end{array}$ & $\begin{array}{l}\text { F: GTGGTGTCATCGGGGTCATT } \\
\text { R: TGAAGTTGTAGCCTGACGAG }\end{array}$ & 129 \\
\hline $\begin{array}{l}\text { P2X3 } \\
\text { ENSE00003538454 }\end{array}$ & $\begin{array}{l}\text { F: GGAAACCTCCTTCCCAAC } \\
\text { R: AAAATCCTGCCCCGCAAA }\end{array}$ & 123 \\
\hline $\begin{array}{l}\text { P2X4 } \\
\text { ENSE00003585161 }\end{array}$ & $\begin{array}{l}\text { F: GGAATATCCTTCCCAACATCA } \\
\text { R: CTCCACGGCCATGTCCT }\end{array}$ & 140 \\
\hline $\begin{array}{l}\text { P2X5 } \\
\text { ENSE00002403617 }\end{array}$ & $\begin{array}{l}\text { F: GCCTAGAAGACAGTTCCCAGGAGG } \\
\text { R: ACACAGATCCGTTCCCCTTCT }\end{array}$ & 168 \\
\hline $\begin{array}{l}\text { P2X6 } \\
\text { ENSE00001347509 }\end{array}$ & $\begin{array}{l}\text { F: AAAGCAACCGCCAACTCTGT } \\
\text { R: GCAAGTGGGTGTCAGAAC }\end{array}$ & 163 \\
\hline $\begin{array}{l}\text { P2X7 } \\
\text { ENSE00001319811 }\end{array}$ & $\begin{array}{l}\text { F: GGACTTCACAGATTGTCC } \\
\text { R: TGGCTTCAGTAAGGACTCT }\end{array}$ & 492 \\
\hline
\end{tabular}


minutes, followed by 45 cycles of denaturation at $95^{\circ} \mathrm{C}$ for 1 minute, annealing at $55-60^{\circ} \mathrm{C}$ for 1 minute and elongation at $72^{\circ} \mathrm{C}$ for $1 \mathrm{~min}$. A final elongation was carried out at $72^{\circ} \mathrm{C}$ for $10 \mathrm{~min}$. PCR products were identified using $1.5 \%$ agarose gels containing SERVA DNA Stain G (SERVA Electrophoresis GmbH, Germany) and visualized under ultraviolet light. Gel images were recorded using G:Box Chemi HR16 BioImaging System (Syngene, UK), densitometry was performed using Fiji distribution of ImageJ (Schindelin et al., 2012).

Protein Extraction and Western blot analysis. Cells $\left(1 \times 10^{6}\right)$ were lysed using RIPA buffer (Thermo Fisher Scientific Inc., USA) supplemented with protease inhibitor mixture (Complete ${ }^{\mathrm{TM}}$, Roche Applied Science, Switzerland). The protein concentration of whole cells extracts was measured using the Protein Assay Kit (BioRad Laboratories, Inc., USA). Samples were resolved using SDS-PAGE on $8 \%$ acrylamide gel (30 $\mu$ g protein per well) and blotted onto nitrocellulose membrane using a Trans-Blot Turbo transfer system (Bio-Rad Laboratories, Inc., USA). Membranes were blocked in fat-free 5\% milk in TTBS (0.25 M Tris-HCl, pH 7.5, $0.15 \mathrm{M} \mathrm{NaCl}$, and $0.1 \%$ Tween-20) and incubated overnight with primary antibody in $4^{\circ} \mathrm{C}$. Following primary antibodies were used: anti-P2X7 (Alomone Labs, Israel; 1 : 250), Monoclonal Anti- $\beta$-Actin-Peroxidase (Sigma-Aldrich, Germany, 1:50000). Anti P2X7 primary antibody was detected using anti-rabbit secondary antibodies conjugated with HRP (Merck Millipore, Germany, 1:10000). The signal from both primary antibodies was visualized using Pierce $^{\text {TM }}$ ECL Western Blotting Substrate (Thermo Fisher Scientific Inc., USA). Immunodetected proteins were imaged on X-Ray film (Kodak), densitometry was performed using Fiji distribution (Schindelin et al., 2012) of ImageJ (Rueden et al., 2017) and integrated density normalized to actin band was averaged between the repeats.

Calcium measurements. Calcium measurements were performed as described previously (Onopiuk et al., 2010), using Fura-2 AM ratiometry (Grynkiewicz et al., 1985). Briefly, glioma cells $\left(1.5 \times 10^{4}\right)$ were seeded on rectangular glass coverslips in $35 \mathrm{~mm}$ dishes the day before the experiment. Cells (50-70\% confluent) were loaded with $50 \mu \mathrm{M}$ Fura-2 AM (ThermoFisher Scientific Inc., USA) in serum-depleted culture medium for $30 \mathrm{~min}$ at $37^{\circ} \mathrm{C}$ in a humidified atmosphere of $95 \%$ air and $5 \%$ $\mathrm{CO}_{2}$. The cells were then washed twice with the solution composed of $5 \mathrm{mM} \mathrm{KCl}, 1 \mathrm{mM} \mathrm{MgCl}, 0.5 \mathrm{mM} \mathrm{Na}_{2} \mathrm{H}$ $\mathrm{PO}_{4}, 25 \mathrm{mM}$ HEPES, $130 \mathrm{mM} \mathrm{NaCl}, 1 \mathrm{mM}$ pyruvate, $5 \mathrm{mM}$ D-glucose, and $0.1 \mathrm{mM} \mathrm{CaCl}_{2}, \mathrm{pH} 7.4$ and the coverslips were mounted in a cuvette containing $1.5 \mathrm{ml}$ $\mathrm{Ca}^{2+}$-containing assay solution (as above but with $2 \mathrm{mM}$ $\mathrm{CaCl}_{2}$ ) and maintained at RT in a RF5001PC spectrofluorimeter (Shimadzu Corp., Japan). Fluorescence was measured at $510 \mathrm{~nm}$ with excitation at 340 and $380 \mathrm{~nm}$ every $1.4 \mathrm{~s}$ for at least $300 \mathrm{~s}$. Excitation and emission slit width was $2.5 \mathrm{~nm}$ and $20.0 \mathrm{~nm}$, respectively. Calcium signal was evaluated as changes in $\mathrm{F}_{340} / \mathrm{F}_{380}$ fluorescence intensity ratio. Specific treatments were applied after at least 60 seconds from the start of the measurement to alleviate the effect of dye bleaching. The cells were treated with $300 \mu \mathrm{M}$ BzATP (Jena Bioscience, Germany).

Propidium iodide dye uptake. Glioma cells were seeded on 6 -well plate $\left(5 \times 10^{3} /\right.$ well $)$ and cultured for 24 hours in standard conditions. Cells were subsequently harvested by trypsinization and washed in $1 \mathrm{x}$ PBS. Next, cells were collected in eppendorf tubes and incubated with propidium iodide (Sigma-Aldrich, Germany) solution $(1 \mathrm{mg} / \mathrm{ml})$ for 15 minutes or co-treated with 100 $\mu \mathrm{M}$ BzATP (Jena Bioscience, Germany) and propidium iodide solution $(1 \mathrm{mg} / \mathrm{ml})$ for 15 minutes. After incubation, cells were washed in 1x PBS and lysed using distilled water to destroy the plasma membrane. Dye fluorescence (ex. $488 \mathrm{~nm}$, em. 617) was measured using Infinite M1000 PRO plate reader (Tecan Trading AG, Switzerland).

MTS assay. MTS (3-(4,5-dimethylthiazol-2-yl)-5-(3carboxymethoxyphenyl)-2-(4-sulfophenyl)-2H-tetrazolium) metabolic activity assay was performed to measure cell viability and growth (Cory et al., 1991). Cells were seeded $\left(5 \times 10^{3} /\right.$ well - U-138, U-251; $1 \times 10^{4} /$ well - C6) on 96-well plate. 24 hours later cells were switched to serum-free DMEM medium supplemented with Gibco N2 supplement (Thermo Fisher Scientific Inc., USA). Cells were treated with $100 \mu \mathrm{M}$ BzATP (Jena Bioscience, Germany), 100 nM BBG (Sigma-Aldrich, Germany) or the combination of both for 24 hours. Cell viability was evaluated with the MTS assay kit (Promega, USA) according to the manufacturer's instructions. The absorbance was read using Sunrise plate reader (Tecan Trading AG, Switzerland) at $490 \mathrm{~nm}$.

LDH assay. LDH (lactate dehydrogenase) assay was performed to measure cell death in glioma cells. Cells were seeded $\left(5 \times 10^{3} /\right.$ well - U-138, U-251; $1 \times 10^{4} /$ well C6) on 96-well plate. 24 hours later cells were switched to serum-free DMEM medium supplemented with Gibco N2 supplement (Thermo Fisher Scientific Inc., USA). Cells were treated with $100 \mu \mathrm{M}$ BzATP (Jena Bioscience, Germany), 100 nM BBG (Sigma-Aldrich, Germany) or the combination of both for 24 hours. The level of released lactate dehydrogenase was evaluated with CytoTox 96® Non-Radioactive Cytotoxicity Assay kit (Promega, USA) according to the manufacturer's instructions. The absorbance was read using Sunrise plate reader (Tecan Trading AG, Switzerland) at $490 \mathrm{~nm}$.

Flow cytometric detection of apoptosis using Annexin V-FITC/PI labeling. Glioma cells were seeded on 6-well plate $\left(5 \times 10^{3} /\right.$ well $)$ and cultured for 24 hours in serumfree DMEM medium supplemented with Gibco N2 supplement (Thermo Fisher Scientific Inc., USA). After that cells were treated with $100 \mu \mathrm{M}$ BzATP. As positive control to confirmation of properly working kit we use Jurkat cells treated by UV-C for 30 seconds. After incubation cells were subsequently harvested by trypsinization and washed in $1 \times$ PBS. Next, cells were collected in eppendorf tubes and incubated with FITC conjugated Annexin $\mathrm{V}$ and propidium iodide (Sigma-Aldrich, Germany) according to the manufacturer's instructions. After incubation, cells were washed in $1 \times$ PBS and analyzed by Guava $^{\circledR}$ easyCyte Flow Cytometer.

Statistical analysis. Plots were generated using Matplotlib 3.1.0 Python library (Hunter, 2007). Data in the box plots are presented as fold change compared to control. The boxes represent 25 and 75 percentile, solid horizontal lines represent median values and whiskers refer to $\pm 1.5 \mathrm{IQR}$ (Interquartile Range). Asterisks represent statistically significant differences in comparison to the control. $n$ refers to the number of independent biological repetitions which contain at least three technical repetitions. Statistical analysis was performed on the raw data using SigmaPlot 12.3 (Systat Software Inc., USA). To assess the differences between the treatments and the control paired t-Student test was used for PI uptake assay data and Repeated-Measures One Way ANOVA followed by Holm-Sidak post-hoc test was used for LDH, MTS assay and Annexin V-PI staining results. Data normality and variance equality were assessed with ShapiroWilk test and Levene's test, respectively. Differences were considered as statistically significant at $p<0.05$. 


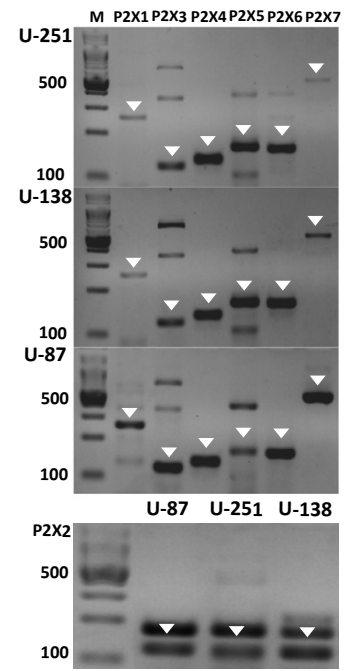

Figure 1. Expression of $\mathrm{P} 2 \mathrm{X}$ receptors in U-251, U-87 and U-138 human glioma cell lines studied using reverse transcriptase PCR (representative result, $n=3$ ).

The bands corresponding to the predicted P2X receptors amplicon sizes are marked by arrowheads. First lane from the left corresponds to the molecular mass DNA marker; 500 and 100 refer to the length in nucleotides.

\section{RESULTS AND DISCUSSION}

\section{Detection of P2Rs mRNA and P2X7 protein}

In order to study the $\mathrm{P} 2 \mathrm{X} 7$ receptor functioning in the human glioma cell lines, we first verified the expression of the receptor mRNA. The reverse transcription PCR assay was performed for all P2X receptors in the three human glioma cell lines (U-138, U-87 and U-251) (Fig. 1). We detected all known P2X receptors in the studied cells. In order to confirm the presence of P2X7 protein in the studied cells, we checked the protein level of P2X7 using Western Blot in the human glioma cell lines and C6 rat glioma cell line as a positive control. All the studied cell lines displayed P2X7 protein presence. However, the obtained results varied greatly between the cell lines as coarse densitometry of P2X7 bands showed differences greater than an order of magnitude (Fig. 2a). The amount of receptor protein in rat glioma C6 line was about seven times greater than the average amount from all human cell lines and almost fifty times greater than in case of U-251. We also observed a profound difference between the human gliomas with U-87 line containing sixteen times more P2X7 protein than U-251 line, while U-138 line had two and half times more of the protein than U-251 (Fig. 2b). Surprisingly, reports on P2X7 expression in human glioma cell lines are rather sparse. In line with our findings, data from The Human Protein Atlas (Thul et al., 2017) confirmed very low levels of P2X7 mRNA in all three human cell lines studied by our team. Moreover, similar results were obtained by (Gehring et al., 2012) on U-138 and U-251 cell mRNA. At the protein level, P2X7 presence in U-87 and U-251 cells was detected by (Ji et al., 2018) using immunofluorescence. The significant difference in band intensity of P2X7 receptor in U-87 cell line in comparison to the other human cells, revealed in our study, may be a result of the problem with U-87 line authenticity reported by (Allen et al., 2016). The authors claimed that the U-87 cell line publicly available in the repositories is not the same cell line that was originally isolated and, therefore, its origin is unknown - with a high probability of being
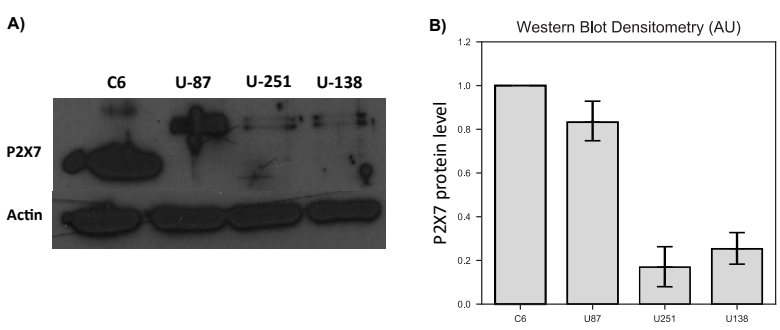

Figure 2. P2X7 receptor protein level shown on the Western Blot (representative result, $n=4$ ).

(A) Representative Western Blot result, from the left: C6 rat glioma cell line U-87 human cell line, U-251 human glioma cell line and U-138 human glioma cell line. (B) The graph shows the results of the quantitative analysis of the Western blots, which was performed using the ImageJ program.

the central nervous system. Thus, we performed $\mathrm{mtD}$ NA sequencing and compared the obtained sequence to the original U-87 cells. It occurred that the cells studied by us were also the non-original ones (see: Supplementary file 1 at https://ojs.ptbioch.edu.pl/index.php/ abp). In the light of the unknown origin of the cells and the vast difference in $\mathrm{P} 2 \mathrm{X} 7$ receptor protein level when compared to our other human cell lines, we decided to omit this cell line during the further experiments.

\section{Calcium influx and large pore formation upon P2X7 stimulation}

To check the physiological activity of P2X7 receptors in the human cell lines and correlate it with receptor gene expression and protein production, we performed a fluorimetric study of intracellular calcium level using Fura-2 AM ratiometric calcium indicator with C6 cell line as a positive control, as described in Methods. The receptors were activated using BzATP, non-hydrolyzing, specific P2X7 receptor agonist. Strong differences were observed between all the studied glioma cell lines (Fig. 3). While C6 cells responded every time BzATP was administered and the strength of the response was similar, the U-251 human cell line responded erratically and U-138 presented absolutely no calcium signal upon BzATP stimulation. While P2X7-dependent calcium increase is not surprising in case of C6 cells (Wei et al., 2008), to our knowledge there are no reports specifically describing presence or absence of P2X7-initiated calcium influx in the two human glioma cell lines. However, P2X7-mediated calcium signals were observed in human astrocytes, murine neural progenitor cells and rat oligodendrocyte precursor cells and all these cell types are top candidates to be the putative cells of origin for glioma (Alloisio et al., 2006; Narcisse et al., 2005; Jiang \& Uhrbom, 2012; Wang et al., 2009; Leeson et al., 2018). The detailed nature of the observed signal is however not exactly clear since there are strong proofs for its metabotropic character (Supłat-Wypych et al., 2010) as well as suggestions of active ATP release through P2X7 receptors (Brandao-Burch et al., 2012).

Our next step in the characterization of P2X7 in human glioma cell lines was to verify the canonical large pore formation upon prolonged P2X7 activation. We performed the propidium iodide uptake assay after 24hour receptor activation with BzATP (Surprenant et al., 1996). The results of the PI uptake experiments correlated with calcium signal studies (Fig. 4), showing lack of significant difference in propidium iodide uptake after BzATP treatment in case of U-138 cells and significant 

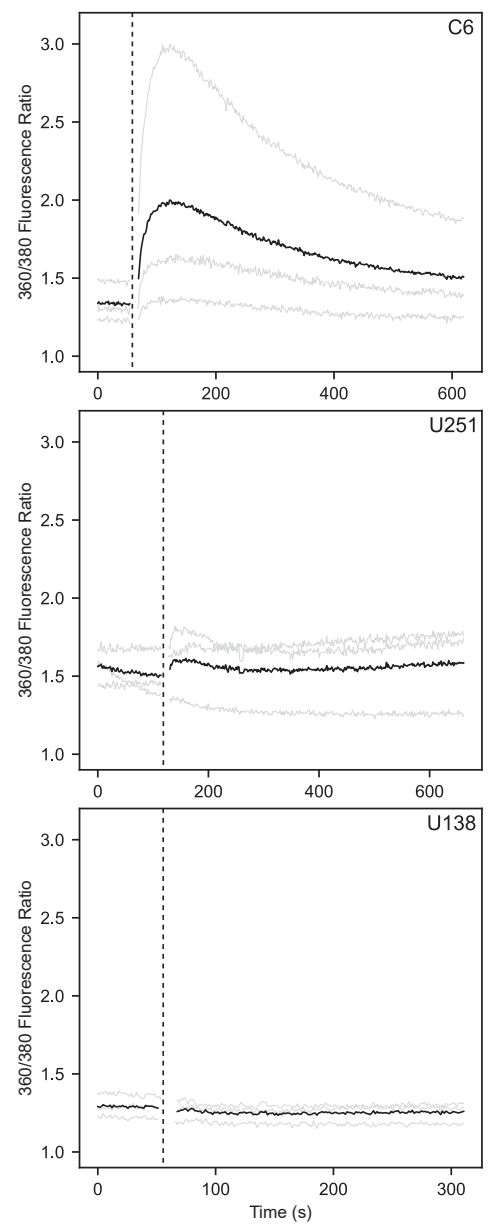

Figure 3. Calcium transient evoked by BzATP administration (dashed line) in:

C6 rat glioma cell line (upper panel), U-251 human glioma cell line (middle panel) and U-138 human glioma cell line (lower panel); for each cell line $n=3$. Gray lines represent the signals from the biological replicates, black lines represent the signal averaged among the individual replicates.

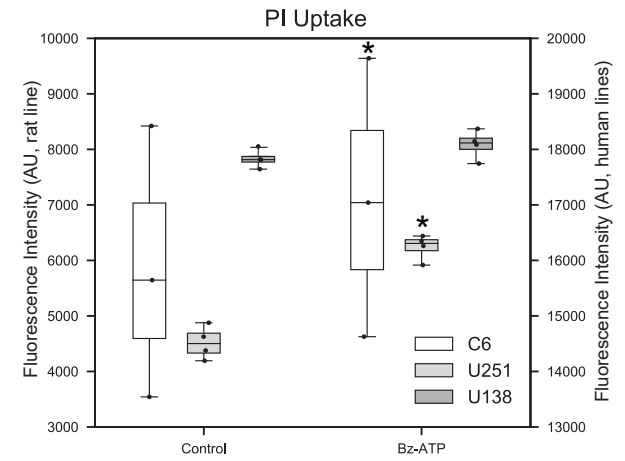

Figure 4. Measurement of propidium iodide uptake level in C6, U-251, U-138 cells.

C6 and U-251 cells showed statistically significant difference between control and BzATP-induced cells (asterisks, $n=3$ and $n=4$, respectively), suggesting the formation of large pore. U-138 control cells did not differ significantly from BzATP-treated ones $(n=4)$. The boxes represent 25 and 75 percentile, solid horizontal lines represent median values and whiskers refer to \pm 1.5 IQR (Interquartile Range). Asterisks represent statistically significant differences in comparison to the control. $n$ refers to the number of independent biological repetitions which contain at least three technical repetitions. The significance of the differences was determined with paired $t$-Student test: ${ }^{*} P \leq 0.05,{ }^{* *} P \leq 0.01,{ }^{* * *} P \leq 0.001$ vs. the respective control.

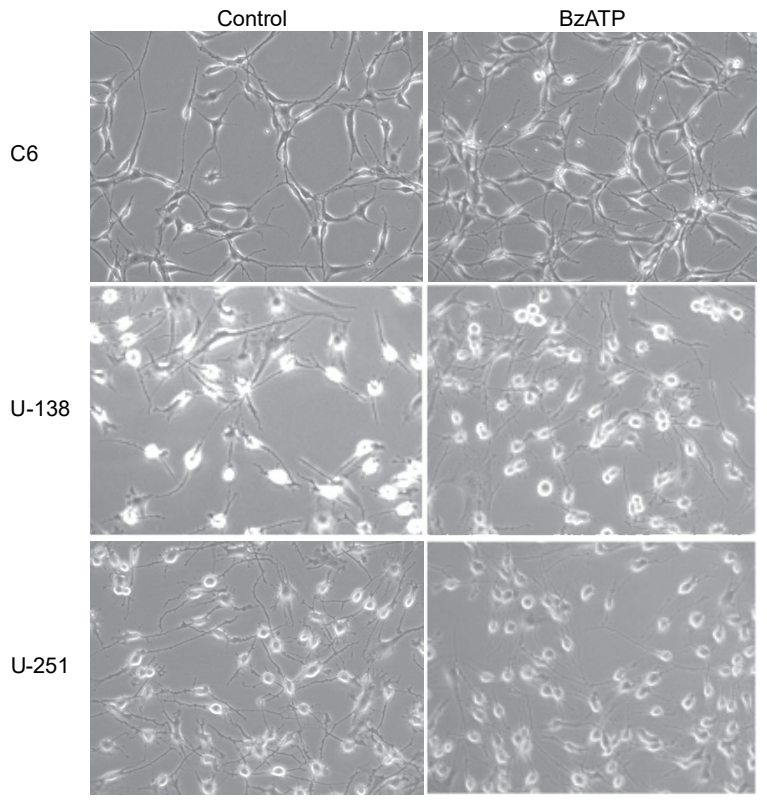

Figure 5. C6, U-251, U-138 glioma cells morphology after 24 hours of P2X7 stimulation.

uptake for C6 and U-251 cells (Fig. 5). Our observations proved that U-138 cells - on the contrary to U-251 are not only unable to develop P2X7-mediated calcium signal, but also unable to form large membrane pore upon prolonged BzATP stimulation. This phenomenon may be explained by the presence of various P2X7 receptor isoforms in the studied cell lines. There are currently twelve known splice variants of $\mathrm{P} 2 \mathrm{X} 7$ receptor (Cheewatrakoolpong et al., 2005; Feng et al., 2006). Cells expressing full-length $\mathrm{P} 2 \mathrm{X} 7 \mathrm{~A}$ receptor isoform demonstrate canonical calcium signaling with plasma membrane permeabilization and cell death. In contrast, P2X7 receptor B isoform still functions as the ATP-mediated calcium channel but is unable to form the pore. There are also several reports showing the influence of the type of P2X7 receptor isoform expression pattern on cancer cells phenotype(Adinolfi et al., 2010; Giuliani et al., 2014). The situation is even more complicated by the possible interactions between the different isoforms expressed in the same cells, observed by (Feng et al., 2006). The researchers revealed that in cervical cancer cells, endogenous, truncated $\mathrm{P} 2 \mathrm{X} 7 \mathrm{j}$ variant blocked the activation of the full-length receptor through the mechanism of heterooligomerization.

\section{Effect of P2X7 stimulation on glioma cell lines viability}

To confirm or exclude the formation of the "death pore" in the studied cell lines, we performed LDH activity assay and Annexin V/PI labeling to verify the effect of P2X7 receptor activation on cell viability. Surprisingly, BzATP stimulation did not have a negative influence on the morphology (Fig. 5) and viability (Fig. 6, Table 2, Supplementary file 3 at https://ojs.ptbioch.edu.pl/index. $\mathrm{php} / \mathrm{abp} /$ ) of the studied cells. Moreover, we performed proliferation assay using MTS test (Cory et al., 1991). In human cell lines, P2X7 stimulation had no effect on their proliferation, whereas in rat glioma C6 cells it even led to a $29 \%$ increase in the number of viable cells (Fig. 7). (Gehring et al., 2012) also observed the lack of apoptosis of U-251 and U-138 after BzATP stimulation, whereas (Ji et al., 2018) obtained increased proliferation in U-87 and U-251 upon P2X7 activation. However, in the lat- 
Table 2. Annexin V/ propidium iodide labeling of C6, U-251, U-138 glioma cells after stimulation with $100 \mu \mathrm{M}$ BzATP for 24 hours.

\begin{tabular}{|c|c|c|c|c|c|}
\hline Cell line & Treatment & Intact cells & Early apoptotic cells & Apoptotic cells & Necrotic cells \\
\hline \multirow{2}{*}{ Jurkat } & non treated & $90.26 \pm 0.06$ & $3.01 \pm 0.07$ & $6.69 \pm 0.03$ & $0.04 \pm 0.05$ \\
\hline & UV-C, 30 seconds & $4.05 \pm 0.16$ & $18.24 \pm 0.2$ & $77.33 \pm 0.12$ & $0.38 \pm 0.08$ \\
\hline \multirow{2}{*}{ C6 } & non treated & $99.87 \pm 0.05$ & $0.07 \pm 0.09$ & $0.0 \pm 0.0$ & $0.03 \pm 0.06$ \\
\hline & BzATP, $100 \mu \mathrm{M}$ & $98.8 \pm 1.08$ & $0.83 \pm 0.06$ & $0.33 \pm 0.04$ & $0.07 \pm 0.09$ \\
\hline \multirow{2}{*}{$U-251$} & non treated & $98.4 \pm 0.45$ & $0.9 \pm 0.22$ & $0.6 \pm 0.28$ & $0.13 \pm 0.05$ \\
\hline & BzATP, $100 \mu \mathrm{M}$ & $97.7 \pm 1.43$ & $1.03 \pm 0.69$ & $0.97 \pm 0.65$ & $0.27 \pm 0.09$ \\
\hline \multirow{2}{*}{ U-138 } & non treated & $98.13 \pm 0.65$ & $1.03 \pm 0.25$ & $0.7 \pm 0.37$ & $0.13 \pm 0.05$ \\
\hline & BzATP, $100 \mu \mathrm{M}$ & $98.13 \pm 0.79$ & $0.9 \pm 0.29$ & $0.77 \pm 0.42$ & $0.17 \pm 0.12$ \\
\hline
\end{tabular}

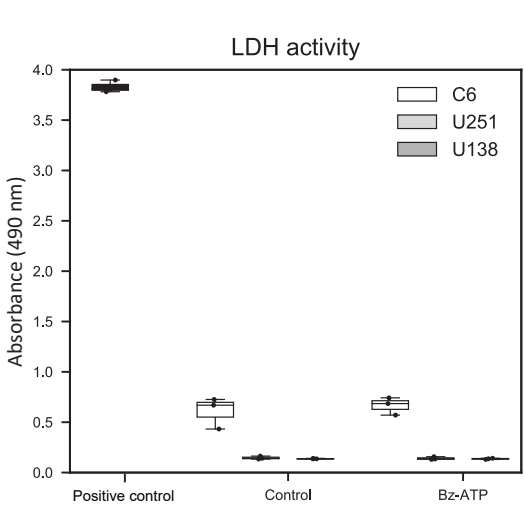

Figure 6. Viability of C6, U-251, U-138 glioma cells after 24 hours of P2X7 stimulation measured by LDH release test $(n=4)$. The boxes represent 25 and 75 percentile, solid horizontal lines represent median values and whiskers refer to \pm 1.5 IQR (Interquartile Range). Asterisks represent statistically significant differences in comparison to the control. $n$ refers to the number of independent biological repetitions which contain at least three technical repetitions. The significance of the differences was determined with a one-way ANOVA with Bonferroni's post hoc test: ${ }^{*} P \leq 0.05,{ }^{* *} P \leq 0.01,{ }^{* * *} P \leq 0.001$ vs. the respective control.

ter case, the proliferation boost might be explained by the use of serum-supplemented cell culture in contrast to serum-free conditions applied in our experiments. While the positive influence of P2X7 on proliferation is wellknown in different cells, it usually is believed to be the effect of truncated receptor isoform expression instead of the full protein and, consequently, of the inability to form the large pore (Cheewatrakoolpong et al., 2005). One example is from (Adinolfi et al., 2010) group, where activation of P2X7B in transfected HEK293 cells, naturally lacking P2X7 receptor expression, increased proliferation via activation of transcription factor NFATc1. Similar results were obtained by (Giuliani et al., 2014) for osteosarcoma cells. However, this explanation does not sufficiently match our observations. Interestingly, the research of (Monif et al., 2009) resulted in similar conclusions to ours. Using P2X7RG345Y mutant which is unable to form the large pore, the team found that P2X7 activation had a significant stimulatory effect on rat microglia activation and proliferation with the phenomenon specifically dependent on the large pore formation. The specific signaling cascades activated after the pore opening and responsible for these observations are still to be revealed though. Therefore, we may speculate that a similar mechanism could be present in glioma cell lines. Finally, P2X7 calcium and pore-forming functions might be severely altered by single nucleotide sequence dif-

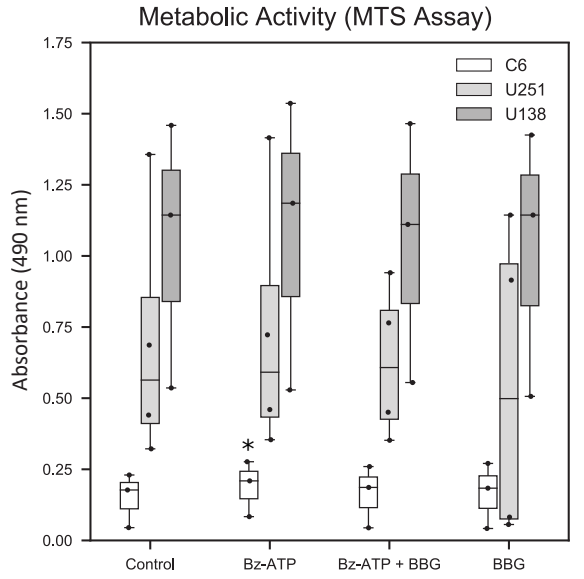

Figure 7. Proliferation of C6 $(n=3), U-251(n=4), U-138(n=3)$ glioma cells upon P2X7 stimulation or inhibition was evaluated by MTS assay.

The boxes represent 25 and 75 percentile, solid horizontal lines represent median values and whiskers refer to \pm 1.5 IQR (Interquartile Range). Asterisks represent statistically significant differences in comparison to the control. $n$ refers to the number of independent biological repetitions which contain at least three technical repetitions. The significance of the differences was determined with a one-way ANOVA with Bonferroni's post hoc test: ${ }^{*} P \leq 0.05,{ }^{* *} P \leq 0.01,{ }^{* *} P \leq 0.001$ vs. the respective control.

ferences between human individuals (Sluyter \& Stokes, 2011). This may be particularly important when interpreting results from single patient-originated cell lines.

\section{CONCLUSIONS}

Our results suggest that despite the presence of $\mathrm{P} 2 \mathrm{X} 7$ receptor $\mathrm{mRNA}$ and protein in all studied cell lines, its activity and physiological effects profoundly differ. In U-138 human cell line, the receptor seemed to be inactive, while in U-251 human and C6 rat cell line P2X7 activation resulted in calcium influx and, finally, large pore formation. However, the proliferation rate of U-138 and U-251 was not affected, whereas for C6 cells a stimulatory effect was observed. These results not only fit into a complicated landscape of P2X7 influence on cancer cells biology but also justify the use of human cell lines in glioma research. Moreover, future studies should take into consideration the existence of different receptor isoforms and be complemented by the animal in vivo experiments which can better mirror the tumor microenvironment and the complicated network of P2X7 and ATP signaling in the brain. 


\section{Acknowledgements}

Authors are also very grateful to Dr. Rafal Czajkowski and Artur Janusz, MSc for their valuable methodological support.

\section{REFERENCES}

Abbracchio MP, Burnstock G, Boeynaems J-M, Barnard EA, Boyer JL, Kennedy C, Knight GE, Fumagalli M, Gachet C, Jacobson KA, Weisman GA (2006) International Union of Pharmacology LVIII: update on the P2Y G protein-coupled nucleotide receptors: from molecular mechanisms and pathophysiology to therapy. Pharmacol. Rev. 58: 281-341. https://doi.org/10.1124/pr.58.3.3

Abbracchio MP, Burnstock G, Verkhratsky A, Zimmermann H (2009) Purinergic signalling in the nervous system: an overview. Trends Neurosci. 32: 19-29. https://doi.org/10.1016/J.TINS.2008.10.001

Adinolfi E, Cirillo M, Woltersdorf R, Falzoni S, Chiozzi P, Pellegatti P, Callegari MG, Sandonà D, Markwardt F, Schmalzing G, Di Virgilio F (2010) Trophic activity of a naturally occurring truncated isoform of the P2X7 receptor. FASEB J. 24: 3393-3404. https:// doi.org/10.1096/fj.09-153601

Allen M, Bjerke M, Edlund H, Nelander S, Westermark B (2016) Origin of the U87MG glioma cell line: Good news and bad news. Sci. Transl. Med. 8: 354re3-354re3. https://doi.org/10.1126/scitranslmed.aaf6853

Alloisio S, Aiello R, Ferroni S, Nobile M (2006) Potentiation of native and recombinant $\mathrm{P} 2 \mathrm{X} 7$-mediated calcium signaling by arachidonic acid in cultured cortical astrocytes and human embryonic kidney 293 cells. Mol. Pharmacol. 69: 1975-83. https://doi.org/10.1124/ mol.105.020164

Anastacio Alves L, Augusto de Melo Reis R, Alves Magalhães de Souza C, Santos de Freitas M, Celso Nogueira Teixeira P, Neto Moreira Ferreira D, Faria Xavier R (2014) The P2X7 receptor: Shifting from a low- to a high-conductance channel - An enigmatic phenomenon? BBA - Biomembr. 1838: 2578-2587. https://doi.org/10.1016/j. bbamem.2014.05.015

Brandao-Burch A, Key ML, Patel JJ, Arnett TR, Orriss IR (2012) The P2X7 receptor is an important regulator of extracellular ATP levels. Front. Endocrinol. (Lausanne) 3: 41. https://doi.org/10.3389/fendo.2012.00041

Burnstock G (1972) Purinergic nerves. Pharmacol. Rev. 24: 509-81

Burnstock G (2007) Physiology and pathophysiology of purinergic neurotransmission. Physiol. Rev. 87: 659-797. https://doi.org/10.1152/ physrev.00043.2006

Cheewatrakoolpong B, Gilchrest H, Anthes JC, Greenfeder S (2005) Identification and characterization of splice variants of the human P2X7 ATP channel. Biochem. Biophys. Res. Commun. 332: 17-27. https://doi.org/10.1016/J.BBRC.2005.04.087

Cory AH, Owen TC, Barltrop JA, Cory JG (1991) Use of an aqueous soluble tetrazolium/formazan assay for cell growth assays in culture. Cancer Commun. 3: 207-12

Feng Y-H, Li X, Wang L, Zhou L, Gorodeski GI (2006) A truncated P2X7 receptor variant (P2X7-i) endogenously expressed in cervical cancer cells antagonizes the full-length P2X7 receptor through hetero-oligomerization. J. Biol. Chem. 281: 17228-17237. https://doi. org/10.1074/jbc.M602999200

Ferrari D, Chiozzi P, Falzoni S, Hanau S, Di Virgilio F (1997) Purinergic modulation of interleukin-1 beta release from microglial cells stimulated with bacterial endotoxin. J. Exp. Med. 185: 579-82. https://doi.org/10.1084/jem.185.3.579

Ferrari D, Los M, Bauer MKA, Vandenabeele P, Wesselborg S, Schulze-Osthoff K (1999) P2Z purinoreceptor ligation induces activation of caspases with distinct roles in apoptotic and necrotic alterations of cell death. FEBS Lett. 447: 71-75. https://doi.org/10.1016/ S0014-5793(99)00270-7

Gehring MP, Pereira TCB, Zanin RF, Borges MC, Filho AB, Battastini AMO, Bogo MR, Lenz G, Campos MM, Morrone FB (2012) P2X7 receptor activation leads to increased cell death in a radiosensitive human glioma cell line. Purinergic Signal. 8: 729-739. https://doi. org/10.1007/s11302-012-9319-2

Gehring MP, Kipper F, Nicoletti NF, Sperotto ND, Zanin R, Tamajusuku ASK, Flores DG, Meurer L, Roesler R, Filho AB, Lenz G, Campos MM, Morrone FB (2015) P2X7 receptor as predictor gene for glioma radiosensitivity and median survival. Int. J. Biochem. Cell Biol. 68: 92-100. https://doi.org/10.1016/J.BIOCEL.2015.09.001

Gieryng A, Pszczolkowska D, Bocian K, Dabrowski M, Rajan WD, Kloss M, Mieczkowski J, Kaminska B (2017) Immune microenvironment of experimental rat C6 gliomas resembles human glioblastomas. Sci. Rep. 7: 17556. https://doi.org/10.1038/s41598-01717752-w

Giuliani AL, Colognesi D, Ricco T, Roncato C, Capece M, Amoroso F, Wang QG, De Marchi E, Gartland A, Di Virgilio F, Adinolfi E (2014) Trophic activity of human P2X7 receptor isoforms A and
B in osteosarcoma. PLoS One 9: e107224. https://doi.org/10.1371/ journal.pone.0107224

Grynkiewicz G, Poenie M, Tsien RY (1985) A new generation of $\mathrm{Ca}^{2+}$ indicators with greatly improved fluorescence properties. J. Biol. Chem. 260: 3440-3450.

Gu BJ, Wiley JS (2018) P2X7 as a scavenger receptor for innate phagocytosis in the brain. Br. J. Pharmacol. 175: 4195-4208. https:// doi.org/10.1111/bph.14470

Hide I, Tanaka M, Inoue A, Nakajima K, Kohsaka S, Inoue K, Nakata Y (2002) Extracellular ATP triggers tumor necrosis factor- $\alpha$ release from rat microglia. J. Neurochem. 75: 965-972. https://doi. org/10.1046/j.1471-4159.2000.0750965.x

Hunter JD (2007) Matplotlib: A 2D graphics environment. Comput. Sci. Eng. 9: 90-95. https://doi.org/10.1109/MCSE.2007.55

Illes P, Khan TM, Rubini P (2017) Neuronal P2X7 receptors revisited: do they really exist? J. Neurosci. 37: 7049-7062. https://doi. org/10.1523/JNEUROSCI.3103-16.2017

Illes P, Burnstock G, Tang Y (2019) Astroglia-derived ATP modulates CNS neuronal circuits. Trends Neurosci. 42: 885-898. https://doi. org/10.1016/j.tins.2019.09.006

Ji Z, Xie Y, Guan Y, Zhang Y, Cho K-S, Ji M, You Y (2018) Involvement of P2X 7 receptor in proliferation and migration of human glioma cells. Biomed Res. Int. 2018: 1-12. https://doi. org/10.1155/2018/8591397

Jiang Y, Uhrbom L (2012) On the origin of glioma. Ups. J. Med. Sci. 117: 113-21. https://doi.org/10.3109/03009734.2012.658976

Kaczmarek-Hajek K, Zhang J, Kopp R, Grosche A, Rissiek B, Saul A, Bruzzone S, Engel T, Jooss T, Krautloher A, Schuster S, Magnus T, Stadelmann C, Sirko S, Koch-Nolte F, Eulenburg V, Nicke A (2018) Re-evaluation of neuronal P2X7 expression using novel mouse models and a P2X7-specific nanobody. Elife 7: https://doi. org/10.7554/eLife.36217

Karasawa A, Michalski K, Mikhelzon P, Kawate T (2017) The P2X7 receptor forms a dye-permeable pore independent of its intracellular domain but dependent on membrane lipid composition. Elife $\mathbf{6}$ : https://doi.org/10.7554/eLife.31186

von Kügelgen I (2019) Pharmacology of P2Y receptors. Brain Res. Bull. 151: 12-24. https://doi.org/10.1016/j.brainresbull.2019.03.010

Lalo U, Verkhratsky A, Pankratov Y (2011) Ionotropic ATP receptors in neuronal-glial communication. Semin. Cell Dev. Biol. 22: 220-228. https://doi.org/10.1016/j.semcdb.2011.02.012

Leeson HC, Kasherman MA, Chan-Ling T, Lovelace MD, Brownlie JC, Toppinen KM, Gu BJ, Weible MW (2018) P2X7 Receptors regulate phagocytosis and proliferation in adult hippocampal and SVZ neural progenitor cells: implications for inflammation in neurogenesis. Stem Cells 36: 1764-1777. https://doi.org/10.1002/stem.2894

Lopatář J, Dale N, Frenguelli BG (2015) Pannexin-1-mediated ATP release from area CA3 drives mGlu5-dependent neuronal oscillations. Neuropharmacology 93: 219-228. https://doi.org/10.1016/i.neuropharm.2015.01.014

Martins I, Tesniere A, Kepp O, Michaud M, Schlemmer F, Senovilla L, Séror C, Métivier D, Perfettini J-L, Zitvogel L, Kroemer G (2009) Chemotherapy induces ATP release from tumor cells. Cell Cycle 8: 3723-3728. https://doi.org/10.4161/cc.8.22.10026

Miras-Portugal MT, Sebastián-Serrano Á, García L de D, Díaz-Hernández M (2017) Neuronal P2X7 receptor: involvement in neuronal physiology and pathology. J. Neurosci. 37: 7063-7072. https://doi. org/10.1523/JNEUROSCI.3104-16.2017

Monif M, Reid CA, Powell KL, Smart ML, Williams DA (2009) The P2X 7 receptor drives microglial activation and proliferation: a trophic role for P2X 7 R pore. J. Neurosci. 29: 3781-3791. https://doi. org/ 10.1523/JNEUROSCI.5512-08.2009

Monif M, O’Brien TJ, Drummond KJ, Reid CA, Liubinas S V, Williams DA (2014) P2X7 receptors are a potential novel target for anti-glioma therapies. J. Inflamm. 11: 25. https://doi.org/10.1186/ s12950-014-0025-4

Mutafova-Yambolieva VN, Durnin L (2014) The purinergic neurotransmitter revisited: A single substance or multiple players? Pharmacol. Ther. 144: 162-191. https://doi.org/10.1016/j. pharmthera.2014.05.012

Narcisse L, Scemes E, Zhao Y, Lee SC, Brosnan CF (2005) The cytokine IL-1? transiently enhances P2X7 receptor expression and function in human astrocytes. Glia 49: 245-258. https://doi. org/10.1002/glia.20110

North RA (2002) Molecular physiology of P2X receptors. Physiol. Rev. 82: 1013-1067. https://doi.org/10.1152/physrev.00015.2002

Onopiuk M, Wierzbicka K, Brutkowski W, Szczepanowska J, Zabłocki K (2010) Caspase-dependent inhibition of store-operated Ca2+ entry into apoptosis-committed Jurkat cells. Biochem. Biophys. Res. Commun. 399: 198-202. https://doi.org/10.1016/j.bbrc.2010.07.054

Panenka W, Jijon H, Herx LM, Armstrong JN, Feighan D, Wei T, Yong VW, Ransohoff RM, MacVicar BA (2001) P2X7-like receptor activation in astrocytes increases chemokine monocyte chemoattractant protein-1 expression via mitogen-activated protein kinase. J. Neurosci. 21: 7135-7142. https://doi.org/10.1523/JNEUROSCI.21-18-07135.2001 
Rivera A, Vanzulli I, Butt AM (2016) A central role for ATP signalling in glial interactions in the CNS. Curr. Drug Targets 17: 1829-1833

Rueden CT, Schindelin J, Hiner MC, DeZonia BE, Walter AE, Arena ET, Eliceiri KW (2017) ImageJ2: ImageJ for the next generation of scientific image data. BMC Bioinformatics 18: 529. https://doi. org/10.1186/s12859-017-1934-z

Ryu JK, Jantaratnotai N, Serrano-Perez MC, McGeer PL, McLarnon JG (2011) Block of purinergic P2X $\mathrm{X}_{7} \mathrm{R}$ inhibits tumor growth in a C6 glioma brain tumor animal model. J. Neuropathol. Exp. Neurol. 70: 13-22. https://doi.org/10.1097/NEN.0b013e318201d4d4

Schindelin J, Arganda-Carreras I, Frise E, Kaynig V, Longair M, Pietzsch T, Preibisch S, Rueden C, Saalfeld S, Schmid B, Tinevez J-Y, White DJ, Hartenstein V, Eliceiri K, Tomancak P, Cardona A (2012) Fiji: an open-source platform for biological-image analysis. Nat. Methods 9: 676-682. https://doi.org/10.1038/nmeth.2019

Sluyter R, Stokes L (2011) Significance of P2X7 receptor variants to human health and disease. Recent Pat. DNA Gene Seq. 5: 41-54

Sperlágh B, Köfalvi A, Deuchars J, Atkinson L, Milligan CJ, Buckley NJ, Vizi ES (2002) Involvement of P2X7 receptors in the regulation of neurotransmitter release in the rat hippocampus. J. Neurochem. 81: 1196-211

Sperlágh B, Illes P (2014) P2X7 receptor: an emerging target in central nervous system diseases. Trends Pharmacol. Sci. 35: 537-547. https:// doi.org/10.1016/J.TIPS.2014.08.002

Suadicani SO, Brosnan CF, Scemes E (2006) P2X7 Receptors mediate ATP release and amplification of astrocytic intercellular $\mathrm{Ca}^{2+}$ signaling. J. Neurosci. 26: 1378-1385. https://doi.org/10.1523/JNEUROSCI.3902-05.2006

Supłat-Wypych D, Dygas A, Barańska J (2010) 2',3'-O-(4-benzoylbenzoyl)-ATP-mediated calcium signaling in rat glioma C6 cells: role of the P2Y2 nucleotide receptor. Purinergic Signal. 6: 317-325. https:// doi.org/10.1007/s11302-010-9194-7

Surprenant A, Rassendren F, Kawashima E, North RA, Buell G (1996) The cytolytic P2Z receptor for extracellular ATP identified as a P2X receptor (P2X7). Science 272: 735-738. https://doi.org/10.1126/SCIENCE.272.5262.735
Tamajusuku ASK, Villodre ES, Paulus R, Coutinho-Silva R, Battasstini AMO, Wink MR, Lenz G (2010) Characterization of ATP-induced cell death in the GL261 mouse glioma. J. Cell. Biochem. 109: 983991. https://doi.org/10.1002/jcb.22478

Thul PJ, Åkesson L, Wiking M, Mahdessian D, Geladaki A, Ait Blal H, Alm T, Asplund A, Björk L, Breckels LM, Bäckström A, Danielsson F, Fagerberg L, Fall J, Gatto L, Gnann C, Hober S, Hjelmare M, Johansson F, Lee S, Lindskog C, Mulder J, Mulvey CM, Nilsson P, Oksvold P, Rockberg J, Schutten R, Schwenk JM, Sivertsson A, Sjöstedt E, Skogs M, Stadler C, Sullivan DP, Tegel H, Winsnes C, Zhang C, Zwahlen M, Mardinoglu A, Pontén F, von Feilitzen K, Lilley KS, Uhlén M, Lundberg E (2017) A subcellular map of the human proteome. Science 356: eaal3321. https://doi.org/10.1126/science.aal3321

Wang L-Y, Cai W-Q, Chen P-H, Deng Q-Y, Zhao C-M (2009) Downregulation of $\mathrm{P}_{2} \mathrm{X}_{7}$ receptor expression in rat oligodendrocyte precursor cells after hypoxia ischemia. Glia 57: 307-319. https://doi. org/10.1002/glia.20758

Wei W, Ryu JK, Choi HB, McLarnon JG (2008) Expression and function of the P2X7 receptor in rat C6 glioma cells. Cancer Lett. 260: 79-87. https://doi.org/10.1016/J.CANLET.2007.10.025

$\mathrm{Xu}$ XJ, Boumechache M, Robinson LE, Marschall V, Gorecki DC, Masin M, Murrell-Lagnado RD (2012) Splice variants of the P2X7 receptor reveal differential agonist dependence and functional coupling with pannexin-1. J. Cell Sci. 125: 3776-3789. https://doi. org/10.1242/jcs.099374

Yegutkin GG (2008) Nucleotide- and nucleoside-converting ectoenzymes: Important modulators of purinergic signalling cascade. Biochim. Biophys. Acta - Mol. Cell Res. 1783: 673-694. https://doi. org/10.1016/J.BBAMCR.2008.01.024

Young CNJ, Górecki DC (2018) P2RX7 Purinoceptor as a therapeutic target - the second coming? Front. Chem. 6: 248. https://doi. org/10.3389/fchem.2018.00248 